\title{
ANALISIS DAN TREN PENGGUNAAN ACCOUNTING CHOICE YANG DILAKUKAN PERUSAHAAN DI INDONESIA PASCA ADOPSI IFRS
}

\author{
Heny Kurniawati \\ Accounting and Finance Department, Faculty of Economic and Communication, BINUS University \\ Jln. K. H. Syahdan No. 9, Palmerah, Jakarta Barat 11480 \\ hkurniawati@binus.edu
}

\begin{abstract}
This study aims to analyze the accounting choice used by Indonesia's public listed companies after IFRS convergence effectively applied in 2011 and 2012. Data used in this study were financial statements of Indonesia's public listed companies in 2011 and 2012. The analysis focused on accounting choice in fixed assets (PSAK 16), intangible assets (PSAK 19), and investment property (PSAK 13). The study showed that public listed companies tend to choose historical cost to account for their fixed assets, intangible assets, and investment property. For fixed assets, it is only $2.5 \%$ changing their accounting policy to revaluation method. While for investment property, it is only 15\% using revaluation method. All of public listed companies used historical cost method to record their non-goodwill intangible assets.
\end{abstract}

Keywords: IFRS convergence, accounting choice, fixed assets, intangible assets, investment property

\begin{abstract}
ABSTRAK
Penelitian bertujuan untuk menganalisis accounting choice yang dipilih perusahaan yang terdaftar di Bursa Effect Indonesia pascapenerapan standar akuntansi hasil konvergensi IFRS efektif tahun 2011 dan 2012. Analisis difokuskan pada PSAK 16 mengenai aktiva tetap, PSAK 19 mengenai aktiva tak berwujud, dan PSAK 13 mengenai properti investasi. Hasil penelitian menunjukkan bahwa perusahaan-perusahaan yang terdaftar di bursa cenderung untuk memilih metode biaya historis untuk mengukur aktiva tetap dan aktiva tak berwujud. Untuk aktiva tetap hanya sebesar 2,5\% dari seluruh perusahaan yang menggunakan metode revaluasi dan untuk properti investasi hanya 15\% saja yang menggunakan metode revaluasi. Sedangkan untuk aktiva tidak berwujud selain goodwill, seluruh pengukurannya menggunakan metode biaya historis.
\end{abstract}

Kata kunci: konvergensi IFRS, accounting choice, aktiva tetap, properti investasi, aktiva tidak berwujud 


\section{PENDAHULUAN}

Indonesia sebagai salah satu anggota G20 telah ikut serta dalam kesepakatan Pemimpin Negara G20 di Washington DC tanggal 15 November 2008 mengenai pencanangan prinsip-prinsip G20. Prinsip G20 tersebut kemudian diperdalam dalam pertemuan G20 di London tanggal 2 April 2009 yang salah satunya adalah "strengthening Financial Supervision and Regulation" dengan salah satu butirnya berbunyi “... achieve a single set of high-quality global accounting standards.”

Berdasarkan kesepakatan tersebut, Ikatan Akuntan Indonesia (IAI) melaksanakan amanat dari Pemerintah RI dengan melakukan konvergensi standar akuntansi nasional ke standar akuntansi internasional. Standar akuntansi internasional yang dimaksud adalah standar yang dikembangkan oleh International Accounting Standard Board (IASB). Dengan demikian, arah standar akuntansi berubah dari yang semula berkiblat ke United States Generally Accepted Accounting Standard Principle (US GAAP) ke IFRS. Konvergensi IFRS tersebut diharapkan dapat (1) memudahkan pemahaman atas laporan keuangan dengan penggunaan Standar Akuntansi Keuangan yang dikenal secara internasional (enhance comparability), (2) meningkatkan arus investasi global melalui transparansi, (3) menurunkan biaya modal dengan membuka peluang fund raising melalui pasar modal secara global, (4) menciptakan efisiensi penyusunan laporan keuangan.

Untuk dapat mencapai hal-hal yang diharapkan tersebut, Dewan Standar IAI telah menyusun roadmap konvergensi IFRS sebagai berikut: (1) Tahap adopsi (2008-2010) dengan agenda mengadopsi seluruh IFRS ke PSAK, mempersiapkan infrastruktur yang diperlukan, dan mengevaluasi dan mengelola dampak adopsi terhadap PSAK yang berlaku; (2) Tahap persiapan akhir (2011) dengan agenda menyelesaikan persiapan infrastruktur yang diperlukan dan menerapkan secara bertahap beberapa PSAK berbasis IFRS; (3) Tahap implementasi (2012) dengan agenda menerapkan PSAK berbasis IFRS secara bertahap dan mengevaluasi dampak penerapan PSAK secara komprehensif

Penelitian ini diharapkan mampu untuk memberikan kontribusi dalam mengevaluasi dampak penerapan PSAK yang telah dikonvergensi ke IFRS baik untuk penerapan standar yang efektif tahun 2011 maupun untuk standar yang efektif tahun 2012. Kontribusi yang dimaksud terkait dengan evaluasi dan tren pemilihan metode akuntansi (accounting choices) oleh penyusun laporan keuangan, dalam hal ini, manajemen pascapenerapan PSAK berbasis IFRS di Indonesia.

\section{Studi Pustaka}

Peranan akuntansi dalam dunia bisnis menjadi nyata karena pasar yang dimiliki adalah pasar yang tidak sempurna dan tidak lengkap. Akuntansi menjadi jembatan atas ketidaksempurnaan pasar sehingga informasi yang tidak simetris di antara pihak-pihak yang mempunyai kontrak dapat tersampaikan. Namun demikian, akuntansi juga mempunyai keterbatasan yang salah satunya adalah penggunaan metode dan prinsip akuntansi yang bervariasi (accounting choice). Accounting choice, menurut Fields (2000) didefinisikan sebagai "any decision whose primary purpose is to influence (either in form or substance) the output of the accounting system in particular way, including not only financial statements published in accordance with GAAP, but also tax returns and regulatory fillings".

Dari definisi tersebut, terlihat bahwa accounting choice mempunyai pengertian yang luas. Francis (2001) menguraikan keluasan pengertian tersebut menjadi dua hal, yaitu sifat pengambil keputusan dan sifat dari pilihan itu sendiri. Keluasan definisi tersebut dari dimensi sifat pengambil keputusan dapat terlihat bahwa dalam definisi tersebut yang dimaksud dengan pengambil keputusan bukan hanya manajer, tetapi juga termasuk auditor, anggota komite audit, dan badan penyusun standar. Sedangkan dari segi sifat pilihan itu sendiri, definisi ini mencakup pemilihan metode akuntansi yang diperbolehkan oleh standar (misalnya pemilihan FIFO atau average dalam penilaian 
inventory), penggunaan estimasi dan judgment (seperti dalam menentukan umur ekonomis aset tetap), keputusan untuk mengungkapkan suatu informasi, keputusan kapan untuk menerapkan suatu aturan akuntansi, aktivitas lobby, pilihan mengenai penyajian laporan keuangan, pilihan mengenai klasifikasi suatu transaksi, pilihan mengenai penyajian agregat, pilihan untuk mendesain suatu transaksi dengan cara tertentu untuk menghasilkan informasi keuangan yang diinginkan, dan pilihan keputusan nyata mengenai produksi dan investasi. Lebih lanjut, Francis (2001) menggambarkan bahwa keluasan dimensi dalam definisi accounting choice oleh Fields et al tersebut meliputi berbagai aktivitas yang terkait dengan informasi akuntansi yaitu dimensi arus kas (apakah accounting choice tersebut mempunyai dampak terhadap arus kas) dan dimensi income (apakah accounting choice tersebut mempunyai pengaruh terhadap income).

Mendasarkan pada teori economics of the firm dan Modigliani dan Miller (MM) mengenai pasar yang lengkap dan sempurna (Modigliani \& Miller, 1958) pasar yang lengkap dan sempurna tidak memerlukan peranan akuntansi. Pada kenyataannya, kita tidak mempunyai pasar yang sempurna dan lengkap sehingga akuntansi sangat berperan di dalam pasar. Sedangkan akuntansi sendiri tidak akan dapat terlepas dari judgment dan estimasi, dan pilihan-pilihan accounting treatment untuk menceritakan substansi transaksi yang terjadi. Dengan demikian, selama akuntansi berperan dalam pasar ekonomi, accounting choice akan selalu ada (Fields, 2000).

Accounting choice akan selalu ada karena adanya tarik menarik antara manfaat dan kerugiannya. Di satu sisi, accounting choice memberikan kesempatan kepada penyusun laporan keuangan untuk mengomunikasikan substansi transaksi yang terjadi secara tepat kepada para penggunanya (Fields, 2000). Misalnya, dalam penentuan masa manfaat suatu aktiva tetap dan pemilihan metode alokasi biaya aktiva tetap tersebut, seorang manajer akan memilih masa manfaat sepuluh tahun dengan metode alokasi biaya menggunakan garis lurus. Untuk aktiva tetap yang lain, perkiraan umur manfaat dan metode alokasi biaya yang sama mungkin saja tidak dapat secara tepat menunjukkan alokasi biaya aktiva tetap tersebut, sehingga harus digunakan metode alokasi yang lain. Namun di sisi lain, accounting choice memberikan ruang kepada manajemen untuk dapat "mengatur" informasi akuntansi yang akan disajikan sesuai dengan tujuannya, yang kemudian dikaitkan dengan earning management (Fields, 2000).

\section{Standar Akuntansi dan Penyusun Standar Akuntansi}

Manajer dapat menggunakan accounting choice dengan beragam motif. Motif yang saling bertentangan tersebut mendorong dibatasinya accounting choice oleh pihak yang berkepentingan. (Watts \& Zimmerman, 1986). Regulator harus mengetahui manfaat dan kerugian penggunaan accounting choice agar dapat menemukan titik optimal penggunaan accounting choice.

Penyusun standar akuntansi harus juga memerhatikan manfaat dan kerugian accounting choice dalam menentukan titik optimal standar akuntansi yang disusunnya agar cukup fleksibel bagi manajemen untuk dapat menceritakan substansi transaksi namun cukup terbatas untuk menggunakannya untuk kepentingan yang merugikan stakeholders. Teori akuntansi diskresi harus melibatkan insentif dan politik penyusun standar akuntansi (Watts \& Zimmerman, 1979). Penelitian Ball pada standar akuntansi internasional menyimpulkan bahwa perbedaan perkembangan struktur hukum dan institusi pada setiap negara memengaruhi kebijakan akuntansinya (Ball, et al, 2000).

\section{Accounting Choice dalam IFRS}

Sejak diterapkannya IFRS di berbagai negara di dunia, banyak penelitian telah dilakukan terutama untuk melihat dampak penerapan standar akuntansi baru terhadap perilaku pelaku bisnis dan perkembangan ilmu akuntansi secara umum. Penelitian terkait accounting choice dalam hubungannya dengan penerapan standar akuntansi internasional yaitu International Financial Reporting Standard (IFRS) antara lain dilakukan oleh Lourenco dan Curto (2010) yang menunjukkan bahwa tipe joint 
venture memengaruhi pilihan manajemen untuk melaporkan beban bunganya menggunakan equity method atau menggunakan proportionate consolidation method. Penelitian tersebut juga memberikan bukti empiris bahwa debt covenant cost dan pemantauan biaya memengaruhi pemilihan alternatif perlakukan akuntansi dalam pelaporan keuangan (Lourenco \& Curto, 2010).

Terkait pilihan pengukuran menggunakan historical cost method atau fair value method dalam pengukuran aset di industri real estate, Quagli dan Avallone (2010) menemukan bahwa pemilihan penggunaan fair value method terkait dengan informasi asimetris, efisiensi konstraktual, dan sifat oportunis manajemen. Lebih lanjut, penelitian ini menunjukkan bahwa ukuran perusahaan berhubungan dengan pemilihan fair value, sedangkan market-to-book ratio berkorelasi negatif dengan pemilihan fair value, sedangkan leverage tidak terbukti memengaruhi pemilihan accounting choice tersebut. Sedangkan Hamberg, et al (2011) mendokumentasikan pilihan menggunakan historical cost atau fair value terkait dengan goodwill impairment yang diatur dalam IFRS 3 dengan menggunakan data perusahaan Swedia. Penelitian Hamberg menunjukkan bahwa goodwill impairment setelah diterapkannya IFRS 3 menunjukkan penurunan dibandingkan dengan beban amortisasi goodwill jika menggunakan standar sebelumnya.

\section{METODE PENELITIAN}

Metode penelitian yang akan dilakukan merupakan penelitian kualitatif dan menggunakan studi kepustakaan. Penelitian ini diharapkan dapat menganalisis dan memetakan tren accounting choice pada perusahaan-perusahaan di Indonesia pascaadopsi IFRS. Data yang digunakan dalam penelitian ini adalah PSAK yaitu aktiva tetap (PSAK 16), aktiva tidak berwujud (PSAK 19), dan properti investasi (PSAK 13), serta laporan keuangan perusahaan-perusahaan yang terdaftar di Bursa Efek Jakarta untuk periode 2011 yang dibagi menjadi sektor-sektor untuk mempermudah analisis. PSAK terkait akan dianalisis dalam hal alternatif-alternatif akuntansi yang disediakan oleh standar tersebut, sedangkan laporan keuangan perusahaan terdaftar akan dianalisis mengenai kecenderungan penggunaan alternatif akuntansi yang ditawarkan oleh standar. Empat standar akuntansi yang terkait diperoleh dari publikasi standar akuntansi IAI yang telah efektif tahun 2011. Data laporan keuangan yang diperlukan dalam penelitian yaitu 433 laporan keuangan perusahaan yang terdaftar di BEI yang diperoleh dengan dengan mengunduh laporan keuangan yang telah diaudit pada tahun pembukuan yang berakhir 31 Desember 2011. Sumber pengunduhan adalah situs resmi dari BEI, pada http://www.idx.co.id.

\section{HASIL PENELITIAN DAN PEMBAHASAN}

Hasil penelitian dibagi menjadi dua bagian, yaitu hasil penelitian terhadap alternatif akuntansi yang ditawarkan oleh standar akuntansi terutama PSAK 16, PSAK 13, dan PSAK 19. Hasil penelitian mengenai kecenderungan pemilihan alternatif-alternatif yang ditawarkan standar oleh pelaku industri yang tercermin dalam laporan keuangan yang telah diaudit pada tahun yang berakhir 31 Desember 2011 yaitu saat standar tersebut telah berlaku efektif.

\section{Alternatif Akuntansi yang Ditawarkan PSAK}

\section{PSAK 16}

PSAK 16 mengatur mengenai aktiva tetap. Yang dimaksud aset tetap adalah aset berwujud yang (a) dimiliki untuk digunakan dalam produksi atau penyediaan barang atau jasa, untuk direntalkan kepada pihak lain, atau untuk tujuan administratif; dan (b) diharapkan untuk digunakan selama lebih 
dari satu periode. Alternatif akuntansi yang signifikan dalam standar akuntansi mengenai aktiva tetap adalah pada pengukuran aktiva tetap setelah pengakuan awal, metode depresiasi yang digunakan, dan penelaahan secara periodik masa manfaat dan metode penyusutan yang digunakan.

Pertama, dalam hal pengukuran aset tetap setelah pengakuan awal, entitas dapat memilih untuk menggunakan model biaya atau model revaluasi. Pada model biaya, setelah pengakuan awal, entitas harus mengukur aset tetap yang dimilikinya sebesar biaya perolehan dikurangi akumulasi penyusutan dan akumulasi rugi penurunan nilai. Sedangkan pada model revaluasi, entitas yang telah memilih menggunakan model revaluasi, setelah pengakuan awal, aset tetap dicatat sebesar pada jumlah revaluasian yaitu nilai wajar pada tanggal revaluasi dikurangi akumulasi penyusutan dan akumulasi rugi penurunan nilai yang terjadi setelah tanggal revaluasi.

Selanjutnya, entitas yang telah memilih metode revaluasi, diharuskan untuk merevaluasi aset tetapnya secara periodik. Namun standar tidak mensyaratkan jangka waktu revaluasi tersebut. Dengan demikian, terbuka pilihan bagi pengguna standar untuk merevaluasi aset tetapnya, misalnya pengguna standar dapat merevaluasi setiap satu tahun, dua tahun, tiga tahun, atau lima tahun selama dilakukan secara periodik. Terkait dengan nilai revaluasi, entitas dapat menggunakan nilai wajar berupa (a) nilai wajar dari penilai, (b) nilai pasar yang ditentukan penilai, (c) pendekatan penghasilan atau biaya pengganti yang telah disusutkan (depreciated replacement cost approach). Sedangkan akumulasi penyusutan untuk entitas yang menggunakan revaluasi, entitas dapat memilih penyajian akumulasi penyusutan dengan dua cara, yaitu: (a) disajikan kembali secara proporsional dengan perubahan dalam jumlah tercatat bruto dari aset sehingga jumlah tercatat aset setelah revaluasi sama dengan jumlah revaluasian dan (b) dieliminasi terhadap jumlah tercatat bruto dari asset dan jumlah tercatat neto setelah eliminasi disajikan kembali sebesar jumlah revaluasian dari aset tersebut. Dalam hal terjadi surplus terhadap revaluasi aset tetap, surplus disajikan dalam ekuitas. Surplus revaluasi aset tetap yang telah dalam ekuitas dapat disajikan oleh entitas dengan dua cara, yaitu: (a) dipindahkan langsung ke saldo laba pada saat asset tersebut dihentikan pengakuannya, atau (b) dipindahkan sebagian sejalan dengan penggunaan asset oleh entitas.

Kedua, untuk metode penyusutan yang digunakan, entitas dapat memilih menggunakan metode penyusutan yang sesuai dengan pola pemanfaatan keekonomian aset tetap. Terdapat empat alternatif metode penyusutan, yaitu: (a) metode garis lurus, yang menghasilkan pembebanan yang tetap selama umur manfaat aset jika nilai residunya tidak berubah, (b) metode saldo menurun, yang menghasilkan pembebanan yang menurun selama umur manfaat aset, (c) metode jumlah unit, yang menghasilkan pembebanan berdasarkan penggunaan atau output yang diharapkan dari suatu aset.

Ketiga, PSAK 16 revisi 2007 pada paragraf 54 mensyaratkan bahwa masa manfaat dan metode penyusutan suatu aset tetap harus ditelaah secara periodik sehingga mencerminkan kondisi yang sebenarnya. Namun standar ini tidak mengharuskan jangka waktu tertentu atas penelaahan masa manfaat dan metode penyusutan tersebut. Dengan demikian pengguna standar dapat memilih waktu penelaahan masa manfaat dan metode penyusutan atas aset tetap yang dimilikinya (IAI, 2011).

\section{PSAK 13}

Menurut PSAK 13 revisi tahun 2007 paragraf 5 yang dimaksud dengan Properti Investasi (Investment Property) adalah properti (tanah atau bangunan atau bagian dari suatu bangunan atau kedua-duanya) yang dikuasai (oleh pemilik atau lessee/penyewa melalui sewa pembiayaan) untuk menghasilkan rental atau untuk kenaikan nilai atau kedua-duanya, dan tidak untuk (a) digunakan dalam produksi atau penyediaan barang atau jasa atau untuk tujuan administratif; atau (b) dijual dalam kegiatan sehari-hari.

Alternatif akuntansi yang signifikan dalam standar ini adalah pada pengukuran setelah pengakuan awal. Pertama, entitas harus memilih untuk menggunakan model biaya atau model nilai 
wajar. Pada model biaya, entitas mengukur properti investasi setelah pengakuan awal sesuai dengan pengukuran PSAK 16, yaitu dicatat sebesar biaya perolehan dikurangi akumulasi penyusutan dan akumulasi rugi penurunan nilai. Pada model nilai wajar, entitas harus menggunakan nilai wajar dalam pengukuran properti investasi setelah pengakuan awal. Nilai wajar adalah nilai yang diperoleh dari transaksi antara pihak-pihak yang memiliki pengetahuan yang memadai dan berkeinginan dalam suatu transaksi yang wajar. Lebih lanjut, paragraf 40 mengatur bahwa dalam menentukan nilai wajar, entitas tidak mengurangi nilai wajar tersebut dengan biaya transaksi yang mungkin timbul dari penjualan atau pelepasan lainnya. Namun baik menggunakan model biaya maupun model nilai wajar, entitas diwajibkan untuk mengungkapkan nilai wajar tersebut dalam catatan atas laporan keuangannya.

Kedua, dalam memperoleh nilai wajar, entitas dianjurkan namun tidak diharuskan untuk menggunakan penilai independen yang diakui dan memiliki kualifikasi profesional yang relevan serta memiliki pengalaman mutakhir di lokasi dan kategori properti investasi yang dinilai. Paragraf tersebut secara implisit mengandung pilihan alternatif akuntansi bagi suatu entitas untuk menggunakan jasa penilai independen atau tidak menggunakan jasa penilai independen.

Ketiga, seperti dijelaskan dalam paragraf 33 bahwa entitas dapat menerapkan model yang berbeda untuk properti investasi yang menjadi agunan kewajiban yang menghasilkan imbalan yang terkait langsung dengan nilai wajar darik atau imbaloan dari, aset tertentu termasuk properti investasi dan seluruh properti investasi yang lain.

Keempat, terkait nilai wajar yang digunakan pada model nilai wajar, PSAK 13 memberikan pilihan akuntansi sesuai dengan keadaan entitas. Nilai wajar dapat mengacu pada (a) harga kini dalam pasar aktif untuk properti serupa dalam lokasi dan kondisi yang sama dan berdasarkan pada sewa dan kontrak lain yang serupa yang merupakan nilai wajar terbaik, (b) harga kini dalam pasar aktif untuk properti yang memiliki sifat, kondisi dan lokasi berbeda, (c) harga terakhir properti serupa dalam pasar yang kurang aktif, dengan penyesuaian untuk mencerminkan adanya perubahan dalam kondisi ekonomi sejak tanggal transaksi terjadi pada harga tersebut, (d) proyeksi arus kas diskontoan berdasarkan estimasi arus kas di masa dengan yang dapat diandalkan (IAI, 2009).

\section{PSAK 19}

Definisi aktiva tak berwujud menurut PSAK 19 adalah aset nonmoneter yang dapat diidentifikasi dan tidak mempunyai wujud fisik. PSAK 19 menggunakan model biaya untuk pengukuran aktiva tak berwujud pada saat perolehan. Sedangkan pengukuran aset tak berwujud setelah perolehan, standar memperbolehkan perusahaan untuk menggunakan dua model yaitu model biaya dan model revaluasi. Aset tak berwujud yang mempunyai umur manfaat tidak terbatas tidak boleh diamortisasi namun perusahaan setiap tahun diharuskan untuk menguji aset tak berwujud tersebut apakah mengalami penurunan nilai. Pengujian atas penurunan nilai aktiva tak berwujud mengacu pada PSAK 48. Standar juga mensyaratkan bahwa perusahaan perlu mengungkapkan rekonsiliasi atas jumlah tercatat aset tak berwujud pada awal dan akhir periode dan menunjukkan kelompok aset tersebut apakah termasuk sebagai aset yang dimiliki untuk dijual atau termasuk dalam kelompok asset lepasan (IAI, 2009). 


\section{Penggunaan Alternatif Akuntansi yang Ditawarkan PSAK oleh Perusahaan yang Terdaftar di BEI Tahun Buku 2011}

PSAK 16

Berdasarkan penelitian terhadap laporan keuangan 405 perusahaan yang terdaftar di Bursa Efek Indonesia (BEI) diketahui bahwa perusahaan cenderung memilih metode biaya dalam pengukuran aset tetap setelah pengakuan awal. Hal ini dapat terlihat pada Tabel 1 berikut.

Tabel 1 Penggunaan Metode dan Jumlah Perusahaan

\begin{tabular}{lr}
\hline \multicolumn{1}{c}{ Penggunaan Metode } & Jumlah Perusahaan \\
\hline metode biaya & 395 \\
metode revaluasi & 6 \\
metode biaya dan revaluasi & 2 \\
tidak ada aset tetap & 1 \\
tidak ada data & 1 \\
\hline Total & $\mathbf{4 0 5}$ \\
\hline
\end{tabular}

Dari tabel tersebut terlihat kecenderungan yang sangat mencolok, 395 dari 406 perusahaan yang terdaftar, memilih menggunakan metode biaya dibandingkan metode revaluasi. Sedangkan perusahaan yang memilih untuk menggunakan metode revaluasi atau kombinasi antara metode biaya dan revaluasi adalah hanya delapan perusahaan.

Perusahaan yang menggunakan metode revaluasi adalah Bank Capital Indonesia dari sektor Banking, Garuda Indonesia (GIAA), Indo Straits (PTIS), dan Sidomulyo Selaras (SDMU) dari sektor Transportation Services, Multi Indocitra (MICE) dari sektor Wholesale and Retail Trade, dan Mulia Industrindo (MLIA) dari sektor Stone, Clay, Glass \& Concrete Products. Sedangkan perusahaan yang menggunakan metode biaya dan metode revaluasi untuk kelas aset yang berbeda adalah Prima Alloysteel Universal (PRAS) dari sektor Automotive \& Allied Products, dan Sarana Menara Nusantara (TOWR) dari sektor Others. Lebih lanjut, untuk perusahaan yang memilih metode revaluasi, mengungkapkan dalam laporan keuangannya berapa sering perusahaan melakukan periode revaluasi seperti Tabel 2 berikut.

Tabel 2 Frekuensi Revaluasi yang Dilakukan Perusahaan Terdaftar yang Menggunakan Metode Revaluasi

\begin{tabular}{lr}
\hline \multicolumn{1}{c}{ Periode Revaluasi } & Jumlah Perusahaan \\
\hline Periode revaluasi satu tahun sekali & 0 \\
Periode revaluasi dua tahun sekali & 1 \\
Periode revaluasi secara berkala & 3 \\
Periode revaluasi tidak diungkapkan & 4 \\
\hline
\end{tabular}

Tabel tersebut menunjukkan bahwa perusahaan cenderung tidak mengungkapkan periode revaluasi yang akan dilakukan terhadap aktiva tetapnya (Multi Indocitra, Indo Straits, Sidomulyo Selaras, dan Sarana Menara Nusantara), sedangkan tiga perusahaan telah mengungkapkan bahwa periode revaluasi akan dilakukan secara berkala sehingga mencerminkan keteraturan namun tidak mengungkapkan berapa tahun sekali akan dilakukan revaluasi (Garuda Indonesia, Mulia Industrindo, dan Prima Alloysteel Universal). Hanya satu perusahaan yang mengungkapkan secara detail bahwa periode revaluasi aktiva tetapnya akan dilakukan dua tahun sekali, yaitu Bank Capital Indonesia. 
Dalam hal dasar nilai metode revaluasi yang digunakan pada metode revaluasi, secara ringkas dapat dilihat pada Tabel 3 berikut.

Tabel 3 Dasar Penentuan Nilai Revaluasi yang Digunakan

\begin{tabular}{lr}
\hline Dasar Penentuan Nilai Revaluasi & Jumlah Perusahaan \\
\hline Nilai wajar dari penilai & 5 \\
Nilai pasar yang ditentukan penilai & 3 \\
Pendekatan depreciated replacement cost approach & 0 \\
Tidak mengungkapkan dasar nilai revaluasi & 0 \\
\hline
\end{tabular}

Tabel tersebut menunjukkan bahwa seluruh perusahaan yang menggunakan metode revaluasi mengungkapkan dasar nilai revaluasiannya. Nilai wajar yang ditentukan oleh penilai independen sebanyak lima perusahaan, sedangkan nilai pasar yang ditentukan penilai digunakan oleh tiga perusahaan.

Selanjutnya untuk penyajian surplus revaluasi, perusahaan terdaftar cenderung menggunakan metode untuk memindahkan surplus revaluasi ke saldo laba saat aset tetap tersebut dihentikan pengakuannya, seperti ditunjukkan Tabel 4 berikut.

Tabel 4 Penyajian Surplus Revaluasi

\begin{tabular}{lc}
\hline \multicolumn{1}{c}{ Penyajian Surplus Revaluasi } & Jumlah Perusahaan \\
\hline $\begin{array}{l}\text { dipindahkan langsung ke saldo laba saat } \\
\text { aset tetap dihentikan pengakuannya }\end{array}$ & 6 \\
\hline $\begin{array}{l}\text { dipindahkan langsung ke saldo laba sejalan } \\
\text { dengan penggunaan aset tersebut }\end{array}$ & 0 \\
\hline tidak mengungkapkan & 2 \\
\hline
\end{tabular}

Mengenai metode penyusutan yang digunakan, baik perusahaan yang menggunakan metode biaya maupun metode revaluasi, kecenderungan perusahaan seperti terlihat pada Tabel 5 berikut.

Tabel 5 Metode Penyusutan yang Digunakan

\begin{tabular}{lr}
\hline Metode Penyusutan yang Digunakan & Jumlah Perusahaan \\
\hline Metode Garis Lurus & 346 \\
Metode Saldo Menurun & 7 \\
Metode Jumlah Unit & 0 \\
Metode Garis Lurus dan Saldo Menurun & 43 \\
Metode Garis Lurus dan Jumlah Unit & 7 \\
Tidak Mencatat Aset & 1 \\
Tidak Ada Data & 1 \\
\hline Total & $\mathbf{4 0 5}$ \\
\hline
\end{tabular}

Pada tabel di atas terlihat bahwa perusahaan terdaftar cenderung menggunakan metode garis lurus dalam menyusutkan aset tetapnya, yaitu sebanyak $85,4 \%$. Sedangkan penggunaan saldo menurun hanya 7 perusahaan atau 1,7\% dan metode jumlah unit 0 perusahaan. Sejumlah 43 perusahaan (10,6\%) menggunakan metode garis lurus dan saldo menurun untuk kelas aset yang berbeda, dan tujuh perusahaan $(1,7 \%)$ menggunakan metode garis lurus dan jumlah unit. Sedangkan untuk review masa manfaat, nilai residu, dan metode penyusutan, perusahaan yang mengungkapkan bahwa review dilakukan setiap akhir periode laporan keuangan adalah sebanyak 271 perusahaan (66,9\%) dan 
sebanyak 132 perusahaan tidak mengungkapkan review masa manfaat, nilai residu, dan metode penyusutan aset tetapnya, seperti terlihat pada Tabel 6.

Tabel 6 Review Masa Manfaat, Nilai Residu, dan Metode Penyusutan

\begin{tabular}{lr}
\hline \multicolumn{1}{c}{ Periode } & Jumlah Perusahaan \\
\hline Satu Tahun & 271 \\
Dua Tahun & 0 \\
Tiga Tahun & 0 \\
Tidak Diungkapkan & 132 \\
Tidak Ada Data & 1 \\
Tidak Mencatat Aset & 1 \\
\hline Total & $\mathbf{4 0 5}$ \\
\hline
\end{tabular}

\section{PSAK 13}

Untuk penerapan PSAK 13 Properti Investasi, sebanyak 86 perusahaan dari 405 perusahaan yang mempunyai aset berupa properti investasi telah menerapkan PSAK 13 dengan rincian penerapan metode sebagai berikut:

Tabel 7 Metode Pengukuran yang Digunakan untuk Properti Investasi

\begin{tabular}{lrr}
\hline Metode yang Digunakan & Jumlah Perusahaan & \\
\hline Metode Biaya & 72 & 83.7 \\
Metode Nilai Wajar & 13 & 15.1 \\
Metode Lain & 1 & 1.2 \\
\hline Total & $\mathbf{8 6}$ & \\
\hline
\end{tabular}

Dari 86 perusahaan yang mempunyai aset berupa properti investasi, sebagian besar menggunakan metode biaya dalam pengukuran setelah tanggal neraca yaitu sebanyak 72 perusahaan atau sebesar $83,7 \%$ sedangkan sebanyak 13 perusahaan atau $15,1 \%$ perusahaan memilih untuk menggunakan metode nilai wajar. Terdapat satu perusahaan yang menggunakan metode selain yang dianjurkan oleh PSAK 13 yaitu menggunakan nilai yang lebih rendah antara jumlah tercatat dan nilai wajar setelah dikurangi dengan biaya penjualan yaitu Asuransi Dayin Mitra (ASDM)

Perusahaan terdaftar yang mempunyai aset berupa properti investasi harus mengungkapkan nilai wajar properti investasi tersebut terlepas dari perusahaan tersebut menggunakan metode biaya atau nilai wajar. Dari penelitian terhadap 86 perusahaan, diperoleh hasil sebagai berikut:

Tabel 8 Dasar Pengungkapan Nilai Wajar

\begin{tabular}{lr}
\multicolumn{1}{c}{ Dasar Pengungkapan Nilai Wajar } & Jumlah Perusahaan \\
\hline Penilai Independen & 39 \\
Bukan Penilai Independen (Manajemen) & 11 \\
Penilai Independen dan Manajemen & 3 \\
Ada Nilai Wajar Namun Tidak Diungkapkan Penilai & 1 \\
Tidak Mengungkapkan Nilai Wajar & 32 \\
\hline Total & $\mathbf{8 6}$ \\
\hline
\end{tabular}

Tabel 8 menunjukkan bahwa perusahaan yang menggunakan penilai independen lebih besar daripada perusahaan yang menggunakan penilaian dari manajemen sendiri masing-masing sebesar 39 dan 11 perusahaan. Tiga perusahaan menggunakan penilai independen untuk sebagian properti 
investasinya, dan menggunakan penilaian dari manajemen untuk sebagian lainnya. Sementara itu, sebanyak 32 perusahaan yang menggunakan metode biaya, sama sekali tidak mengungkapkan nilai wajar properti investasi dan satu perusahaan telah mengungkapkan nilai wajar namun tidak mengungkapkan dasar nilai wajar yang disajikan.

Sebagian besar perusahaan yang mempunyai properti investasi tidak mengagunkan asetnya yaitu sebanyak 70 perusahaan. Sedangkan sejumlah 12 perusahaan yang mengagunkan tetap menggunakan metode biaya dalam pengukuran properti investasinya, empat perusahaan mengagunkan asetnya dan menggunakan metode nilai wajar dalam pengukurannya.

Perusahaan terdaftar belum sepenuhnya mengungkapkan nilai wajar yang digunakan dalam catatan atas laporan keuangannya, terutama untuk perusahaan yang menggunakan metode biaya. Hal ini terlihat dari 60 perusahaan dari 86 perusahaan yang tidak mengungkapkan nilai wajar properti investasinya ecara rinci dapat dilihat pada Tabel 9.

Tabel 9 Dasar Penentuan Nilai Wajar

\begin{tabular}{lc}
\hline \multicolumn{1}{c}{ Dasar Nilai Wajar } & Jumlah Perusahaan \\
\hline harga pasar aktif properti serupa lokasi sama & 9 \\
harga kini pasar aktif properti serupa lokasi berbeda & 0 \\
harga terakhir pasar tidak aktif yang disesuaikan & 0 \\
proyeksi arus kas diskontoan & 10 \\
harga pasar aktif properti serupa lokasi sama dan proyeksi arus kas diskontoan & 3 \\
harga pasar aktif properti serupa lokasi sama, harga kini pasar ktif properti & 1 \\
serupa lokasi berbeda, dan proyeksi arus kas diskontoan & 1 \\
proyeksi arus kas diskontoan dan NJOP & 1 \\
sebagian diungkapkan menggunakan NJOP & 60 \\
tidak diungkapkan & $\mathbf{8 5}$ \\
\hline Total & \\
\hline
\end{tabular}

Terdapat sembilan perusahaan yang menggunakan harga pasar aktif properti serupa di lokasi yang sama sebagai dasar nilai wajar sedangkan sepuluh perusahaan menggunakan arus kas diskontoan.

\section{PSAK 19}

Untuk penerapan PSAK 19, dari 405 perusahaan yang terdaftar hanya 21 perusahaan yang mengakui aktiva tak berwujud selain goodwil. Hampir seluruh aktiva tak berwujud yang diakui berupa perangkat lunak komputer. Seluruh perusahaan yang mempunyai aktiva tetap diukur menggunakan metode biaya setelah pengakuan awal dan hanya dua perusahaan yang mengungkapkan kebijakan akuntansi untuk mereview masa manfaat, estimasi nilai residu, dan metode penyusutan setiap tahun, sedangkan sisanya sejumlah 19 perusahaan tidak mengungkapkan hal tersebut.

\section{SIMPULAN}

Berdasarkan hasil penelitian, dapat disimpulkan bahwa perusahaan yang terdaftar di Bursa Efek Indonesia cenderung memilih alternatif akuntansi yang menghindari nilai wajar (fair value), sedangkan nilai wajar atau nilai revaluasi kurang dipilih. Hal tersebut terlihat dari pemilihan alternatif akuntansi untuk aset tetap, properti investasi, dan aset tidak berwujud. Untuk aset tetap, 97,5\% memilih tetap menggunakan metode biaya, dan hanya sekitar 2,5\% yang mengubah kebijakan akuntansi aset tetapnya menggunakan metode revaluasi. Untuk perusahaan yang menggunakan metode revaluasi pun masih belum lengkap dalam pengungkapannya dalam catatan atas laporan keuangannya. 
Demikian pula untuk aset tak berwujud, seluruh perusahaan yang mengakui aset tak berwujud menggunakan metode biaya. Hal ini agak berbeda pada penerapan standar untuk properti investasi. Walaupun penggunaan metode biaya masih lebih dominan daripada metode nilai wajar, pada properti investasi lebih banyak perusahaan menggunakan nilai wajar dibandingkan dengan pada penerapan standar pada aset tetap dan aset tidak berwujud.

\section{Saran}

Penelitian selanjutnya untuk memperdalam penerapan PSAK baru ini sangat dimungkinkan dengan meneliti lebih lanjut untuk menjawab berbagai pertanyaan tentang alasan perusahaan yang tercatat di bursa lebih memilih menggunakan metode biaya daripada metode nilai wajar atau revaluasian untuk aset tetap, properti investasi, dan aset tak berwujudnya. Selain itu, untuk memperdalam penerapan PSAK baru ini penelitian lebih lanjut dapat menjawab berbagai pertanyaan tentang faktor-faktor yang memengaruhi pemilihan kebijakan akuntansi suatu perusahaan.

\section{DAFTAR PUSTAKA}

Ball, R., Kothari, S., \& Robin, A. (2000). The Effect of International Institutional Factors on Properties of Accounting Earnings. Journal of Accounting and Economics 29 , 1-52.

Fields, T. L. (2000). Empirical Research on Accounting Choice. Journal of Accounting and Economics 31, pp. 255-307.

Francis, J. (2001). Discussion of empirical research on accounting choice. Journal of Accounting and Economics 31, 309-319.

Hamberg, M., Paananen, M., and Novak, J. (2011). The Adoption of IFRS 3: The Effects of Managerial Discretion and Stock Market Reactions. European Accounting Review, Vol. 20, No. 2, pp. 263-288.

Ikatan Akuntan Indonesia. (2007). Pernyataan Standar Akuntansi Keuangan No. 16 Aset Tetap.

Berwujud.

(2009). Pernyataan Standar Akuntansi Keuangan No. 19 Aset Tak

(2011). Pernyataan Standar Akuntansi Keuangan No. 13 Properti Investasi

Lourenco, I. C., and Curto, J. D. (2010). Determinants of the accounting choice between alternative reporting methods for interests in jointly controlled entities. European Accounting Review, Vol. 19 Issue 4, pp. 739-773.

Modigliani, F., and Miller, M. (1958). The Cost of Capital, Corporation Finance and the Theory of Investment. American Economic Review 48, pp. 261-297.

Quagli, A., and Avallone, F. (2010). Fair value or cost model? Drivers of choice for IAS 40 in real estate industry. European Accounting Review, Vol. 19 Issue 3, pp. 461-493.

Watts, R. L., and Zimmerman, J. L. (1986). Positive Accounting Theory. Englewood Cliff, New Jersey: Prentice Hall.

(1979). The Demand for and Supply of Accounting Theories, the Market for excuses. The Accounting Review 54, pp. 273-305. 